\title{
JEL 038
}

\section{AXAPOB O.B.}

acniрант

Інститут проблем ринку та економіко-екологічних досліджень НАНУ

Франиузький бульвар, 29, м. Одеса, Украӥна, 65044

E-mail: aleksandr-zakhar@mail.ru

ORCID: 0000-0001-9497-1323

\section{ПЛАТФОРМОВІ ТЕХНОЛОГІЇ ФІНАНСУВАННЯ РОЗВИТКУ РИНКУ ІННОВАЦІЙНИХ ТЕХНОЛОГІЙ В УКРАЇНІ}

\begin{abstract}
Актуальність. Актуальність проблеми розвитку ринку інноваційних технологій в обумовлюється тим, що, незважаючи на високу пріоритетність і великі зусилля Украӥни щуодо розвитку ринку інновачійних технологій, тобто ичфрової трансформації, інновачій $і$ стартапів, як $і$ раніше, залишаються досить низькими показники інновачійності економіки, рівня розвитку стартапів, кількості стартапів та їх частки в національній економічі. 3 нашої краӥни продовжується активний відтік висококваліфікованої робочої сили $i$ знань, щчо визначають конкурентоспроможність інноваційних процесів $i$ систем, а отже, потенціалу розвитку ринку інноваційних технологій. Однією з найважливіших чинників такого стану $\epsilon$ дефіциит фінансових ресурсів у знов створюваних малих інноваційних підприємницьких структур (стартапів).

Мета та завдання. Метою статті є виявлення перспективних інноваційних інструментів фінансування малих інноваційних підприємницьких структур (стартапів) та дослідження необхідності їх державного регулювання.
\end{abstract}

Результати. Дослідження дозволило віднести до фінансової складової підприємницького середовища інвесторів, які підтримують різні етапи життєвого ичиклу інноваційного проєкту, від прототипу до первинного публічного розміщення акцій (IPO); бізнес-янголів, які фінансують ранні етапи інноваційного проєкту; посівні фонди; краудфандингові спільноти і платформи; венчурні фонди; банки; установи, щяо надають гранти, та установи, щзо надають державну фінансову підтримку; великі технологічні компанії, що фінансують стартапи для власних потреб. Виявлено, що важливим напрямком інвестування заощаджень громадян Украӥни у стартапи може стати краудфандинг, адже фінансового ринку майже не існує, для інвестування у нерухомість потрібні великі кошти, інвестування в золото - довгострокове і ризиковане. При цььому встановлено, щзо, з одного боку, відсутність спеціального регулювання краудфандингу спрощує збір грошей, а з іншого, відсутні будь-які гарантії для вкладених інвестицій, щзо значно збільшує ризики $і$ так ризикованого вкладення коштів в інноваційні проєкти. Тому необхідним є розробка і прийняття закону, який врегулював би діяльність краудфандингу в Украӥні, щуо дозволило б збирати кошти для інноваційних проектів за спрощеною процедурою. Основні положення цього закону можуть бути адаптованими для Украӥни положеннями регламенту ЄС, що регулює діяльність краудфандингових платформ, який можна розглядати як базу для розробки украӥнського закону, особливо в частині гарантій захисту інвесторів.

Висновки. Проведене дослідження дозволило виявити перспективний для фінансування малих інноваційних підприємницьких структур (стартапів) інноваційний інструмент - краудфандинг (та його різновид краудінвестинг). Враховуючи, щзо в Украӥні, з одного боку, відсутність спеціального регулювання спрощує збір фінансових ресурсів на реалізацію інновачійних проєктів, а з іншого, відсутні будь-які гарантіі для вкладених інвестищій, щуо значно збільшує ризики вкладення коштів в інноваційні проєкти, проаналізовано регуляторну базу ЄС щзодо краудфандингу та доведено необхідність ї̈ адаптащії до нормативно-правової бази України.

Ключові слова: ринок інновачійних технологій, фінансовий інструмент, краудфандинг, краудінвестинг, підприємницьке середовище, інноваційний проєкт, стартап.

\section{ZAHAROV O.V. postgraduate} Institute of Market Problems and Economic and Environmental Research of the National Academy of Sciences of Ukraine French Boulevard, 29, Odessa, Ukraine, 65044

E-mail: aleksandr-zakhar@mail.ru

ORCID: 0000-0001-9497-1323 


\section{PLATFORM TECHNOLOGIES OF FINANCING THE DEVELOPMENT OF THE MARKET OF INNOVATIVE TECHNOLOGIES IN UKRAINE}

Topicality. The urgency of the problem of innovation technology development in Ukraine is due to the fact that, despite the high priority and great efforts of Ukraine to develop the innovation technology market, ie digital transformation, innovation and startups, still remain quite low innovation rates, the level of startups, the number of startups and their share in the national economy. From our country the active outflow of highly skilled workforce and the knowledge defining competitiveness of innovative processes and systems, and consequently, potential of development of the market of innovative technologies proceeds. One of the most important factors in this situation is the lack of financial resources in the newly created small innovative business structures (startups).

Aim and tasks. The purpose of the article is to identify promising innovative tools for financing small innovative business structures (startups) and study the need for state regulation.

Research results. The study allowed to include in the financial component of the business environment investors who support various stages of the life cycle of the innovation project, from the prototype to the initial public offering (IPO); business angels who finance the early stages of an innovation project; sowing funds; crowdfunding communities and platforms; venture funds; banks; institutions providing grants and institutions providing state financial support; large technology companies that finance startups for their own needs. It was found that crowdfunding can be an important area of investing the savings of Ukrainian citizens in startups, because the financial market is almost nonexistent, investing in real estate requires large funds, investing in gold is long-term and risky. It was found that, on the one hand, the lack of special regulation of crowdfunding simplifies fundraising, and on the other hand, there are no guarantees for investment, which significantly increases the risks and so risky investing in innovative projects. Therefore, it is necessary to develop and adopt a law that would regulate crowdfunding in Ukraine, which would raise funds for innovative projects under a simplified procedure. The main provisions of this law can be adapted for Ukraine by the provisions of the EU regulation governing crowdfunding platforms, which can be considered as a basis for the development of Ukrainian law, especially in terms of guarantees of investor protection.

Conclusion. The study revealed a promising innovative tool for financing small innovative business structures (startups) - crowdfunding (and its kind of crowdfunding). Given that in Ukraine, on the one hand, the lack of special regulation simplifies the collection of financial resources for the implementation of innovative projects, and on the other hand, there are no guarantees for investment, which significantly increases the risks of investing in innovative projects, the EU regulatory framework crowdfunding and proved the need to adapt it to the regulatory framework of Ukraine.

Keywords: market of innovative technologies, financial instrument, crowdfunding, crowdfunding, business environment, innovation project, startup.

Постановка проблеми та її зв'язок із важливими науковими та практичними завданнями. Незважаючи на високу пріоритетність і великі зусилля України щодо розвитку ринку інноваційних технологій, тобто цифрової трансформації, інновацій і стартапів, як і раніше, залишаються досить низькими показники інноваційності економіки, рівня розвитку стартапів, кількості стартапів та їх частки в національній економіці.

3 нашої країни продовжується активний відтік висококваліфікованої робочої сили і знань, що визначають конкурентоспроможність інноваційних процесів і систем, а отже, потенціалу розвитку ринку інноваційних технологій. Також наша країна має не досить високі показники у міжнародних рейтингах інноваційного розвитку та, особливо, конкурентоспроможності (табл. 1).

Таблиця 1

Рейтинг України у міжнародних індексах

\begin{tabular}{|l|c|c|}
\hline \multicolumn{1}{|c|}{ Країни } & $\begin{array}{c}\text { Глобальний індекс інновацій } \\
2020[1]\end{array}$ & $\begin{array}{c}\text { Глобальний індекс } \\
\text { конкурентоспроможності 2019 [2] }\end{array}$ \\
\hline Швейцарія & 1 & 5 \\
\hline Швеція & 2 & 8 \\
\hline США & 3 & 2 \\
\hline ФРГ & 9 & 7 \\
\hline Польща & 38 & 37 \\
\hline Україна & 45 & 85 \\
\hline
\end{tabular}

Такий стан обумовлюється, головним чином, недосконалістю фінансової складової підприємницького середовища, а саме доступу суб'єктів ринку інноваційних технологій до фінансування. Тим більше, що під впливом цифровізації світової економіки фінансова складова підприємницького середовища країн трансформується шляхом розширення використання платформових технологій. 
Отже, виникає необхідність виявлення перспективних інноваційних інструментів фінансування малих інноваційних підприємницьких структур (стартапів) та дослідження необхідності їх державного регулювання.

Аналіз останніх публікацій по проблемі. Дослідженням проблем фінансування інноваційного розвитку присвячено дослідження багатьох вчених, зокрема, Cornelli, G., J. Frost, L. Gambacorta, R. Rau, R. Wardrop, T. Ziegler [3], Дж. Фрост, Л. Гамбакорта, Хюн Сон Шин [4], Gilinsky D., Levites P., Gabbay Z. [15]. Виділення невирішених раніше частин загальної проблеми: але проблема фінансування розвитку ринку інноваційних технологій в Україні досі остаточно не вирішена $\mathrm{i}$ потребує подальших досліджень у напрямку пошуку перспективних інноваційних інструментів фінансування.

Формулювання цілей дослідження (постановка завдання). Таким чином, метою статті є виявлення перспективних інноваційних інструментів фінансування малих інноваційних підприємницьких структур (стартапів) та дослідження необхідності їх державного регулювання для розвитку в Україні ринку інноваційних технологій.

Виклад основних результатів та їх обгрунтування. Проведені дослідження дозволили віднести до фінансової складової підприємницького середовища:

- інвесторів, які підтримують різні етапи життєвого циклу інноваційного проєкту, від прототипу до первинного публічного розміщення акцій (IPO);

- бізнес-янголів, які фінансують ранні етапи інноваційного проєкту;

- посівні фонди;

- краудфандингові спільноти і платформи;

- венчурні фонди;

- банки;

- установи, що надають гранти;

- установи, що надають державну фінансову підтримку.

У світі до них додались великі технологічні компанії. За останні десять років відбулося значне зростання фінансування стартапів з боку великих технологічних компаній, величина якого в 2019 році оцінювалася в 572 млрд. доларів [3].

Це стало можливим завдяки тому, що цифрові технології можуть покращувати оцінку ризику за рахунок використання тих же даних, які є природним побічним продуктом ведення відповідної діяльності. Це особливо актуально в разі таких послуг, як кредитування, а також для інвестицій i страхування. Кредитні рейтинги, засновані на супермасивах даних і машинному навчанні, часто можуть бути краще традиційних оцінок, особливо у випадку позичальників 3 недостатньою кредитною історією [4].

Хоча для України, яка поки що не має власних великих технологічних компаній, цей шлях фінансування інноваційного розвитку практично недоступний, окрім ІТ-технологій. Але і в цьому напрямку українські програмісти, в основному, не презентують власні проєкти, а розробляють конкретні програмні продукти для іноземних компаній.

Для українців може стати важливим напрямком інвестування заощаджень ще одне платформове рішення для фінансування інноваційного розвитку - краудфандинг, адже фінансового ринку в нашій країні майже не існує, для інвестування у нерухомість потрібні великі кошти, а інвестування в золото - довгострокове і ризиковане.

У доповіді ОЕСР «New Approaches to SME and Entrepreneurship Financing: Broadening the Range of Instruments» відзначається, що ринок інструментів краудфандингу помітно зріс за останні роки $\mathrm{i}$ буде грати одну з головних ролей у фінансуванні МСП [5].

Першими краудфандинговими платформами були: IndieGoGo (2008) [6], KickStarter (2009) [7], RocketHub (2010) [8]. Вони використовують модель, при якій вкладник за свою участь отримує заздалегідь визначену нагороду (сувенір, зразок продукту, публічну подяку тощо), яка отримала назву умовно-поворотного краудфандингу (інакше - «класичний» краудфандинг).

Крім того, згідно з даними, наведеними на статистичному порталі Statista, загальний обсяг краудфандингу в світі з 2012 року по 2015 рік зріс більш ніж у 9 разів (з 2,7 млрд. дол. США до 24,4 млрд. дол. США) [9]. А за даними Forbes, загальний обсяг краудфандингу подолає планку в 300 млрд дол. США у 2025 році [10].

Основні переваги краудфандингу для стартапів це [11]:

- можливість швидко оцінити своєчасність ідеї і інтерес з боку великого числа потенційних клієнтів; 
- можливість залучити початкові кошти від великого числа невеликих вкладників і, на відміну від венчурного інвестора, отримати більший контроль за майбутнім проектом;

- краудфандінг, як правило, може послужити трампліном до переговорів вже 3 великими інвесторами, тому що він являє собою значну частину перевіреного попиту, яку можна масштабувати;

- швидкий запуск бізнес-ідеї;

- можливість залучити зацікавлених менторів, фахівців і співзасновників до інноваційного проєкту, тому що на платформі краудфандингу вже є середовище, де обертаються потенційні інтересанти подібних ідей. I тому вони готові вкласти кошти і, можливо, взяти участь у реалізації проєкту особисто;

- усі вкладники проєкту є потенційними споживачами продукту або послуги проєкту.

Для високотехнологічних стартапів, венчурних проектів i підприємств, які не можуть дозволити собі боргове навантаження, тому що не мають стабільного грошового потоку, переважним $\epsilon$ краудінвестинг - різновид краудфандингу, коли інвестори в якості винагороди отримують частку в капіталі інвестованого проекту.

Відмінними рисами краудінвестингу є: значно менша порівняно 3 іншими інструментами прямих і венчурних інвестицій мінімальна сума; більша кількість учасників; використання, крім мережі Інтернет, ще й стандартизованих контрактів.

Краудінвестинг дозволяє значній кількості громадян стати власниками нових бізнесів i технологій, взяти участь в їх розвитку не тільки фінансово, а і шляхом вкладення інтелектуального peсурсу. Так, за даними Cambridge Centre for Alternative Finance [12], тільки за 2016 рік за допомогою краудфінансування по всьому світу було профінансовано більше 400000 компаній на суму трохи менше 51,9 млрд. дол. США і з них понад 10000 - це венчурні компанії ранніх стадій.

На жаль, в Україні є всього три краудфандигових майданчики: «Спільнокошт», «На старті» (2019 р.) та «Куб» (Приватбанк). Перші два майданчики спеціалізуються на творчих (фінансування кіно) i соціальних (освітні програми для дітей) ініціативах. На третій платформі частіше зустрічаються бізнес-проекти - масштабування виробництва, наймання додаткових працівників, відкриття нових торгових точок, але не інноваційні проєкти.

Прибуток інвесторів 3 проектів «КУБ» чітко диференційований: вклавши 1000 грн., інвестор отримає 230 грн. на рік. Інвестувавши більше 20 тис. грн., можна розраховувати на додаткові 4600 грн. за рік. Крім того, всі вклади на цьому майданчику застраховані [13].

До того ж Приватбанк - державна банківська установа, тому може перевіряти розробників проектів, з метою запобігання шахрайству. А на практиці проекти зазвичай розміщують, крім спеціально створеної платформи, на власному веб-сайті або facebook-сторінці автора проекту, що не захищає потенційних інвесторів від шахрайства та втрати коштів.

Інвестовані кошти, оскільки краудфандинг в нашій країні спеціально не регулюється, розглядають як «подарунок», тобто ставка податку на них складає 5\% - для коштів від резидентів і 18 $\%$ - для коштів від нерезидентів.

3 одного боку, відсутність спеціального регулювання спрощує збір грошей на реалізацію проєктів, а з іншого, відсутні будь-які гарантії для вкладених інвестицій, що значно збільшує ризики і так ризикованого вкладення коштів в інноваційні проєкти. Так, у правилах «Спільнокошту» $є$ розділ 5 «Обмеження відповідальності», де прописана відсутність будь-якої відповідальності майданчику перед учасниками.

Тому необхідно констатувати, що необхідним є розробка і прийняття закону, який врегулював би діяльність краудфандингу, що дозволило б збирати кошти для інноваційних проектів за спрощеною процедурою.

Оптимальним шляхом було б адаптувати регламент і положення, що регулюють діяльність краудфандингових платформ в СС, які можна розглядати як базу для розробки українського закону «Про краудфандинг».

Так, регулювання краудфандингової діяльності в СС орієнтоване на три об'єкти:

- організацію-посередника, яка управляє платформою краудфандингу (тобто онлайнмайданчиком);

- юридичних або фізичних осіб, які шукають фінансування через краудфандингову платформу (власники проекту);

- інвесторів.

У межах регулювання краудфандингових платформ в СС краудфандингова послуга 
визначається як узгодження інтересів інвесторів і власників проектів у фінансуванні бізнесу за допомогою використання «краудфандингового майданчика» і включає одну з таких дій:

- сприяння наданню позик (тобто краудфандинг на основі позик в Європі);

- розміщення без строгих зобов'язань перекладних цінних паперів та «допущених інструментів для краудфандингових цілей», випущених власниками проектів, та отримання відповідних клієнтських замовлень (краудфандинг на основі інвестицій в Європі).

Платформа краудфандингу визначається як «загальнодоступна інформаційна система в Інтернеті, керована провайдером послуг краудфандингу».

В даний час кілька держав-членів $Є С$ впровадили внутрішні спеціальні режими регулювання краудфандингу, які розрізняються відносно умов роботи краудфандингових платформ, обсягу дозволеної діяльності та вимог до авторизації.

3 метою усунення цієї розбіжності було прийнято Положення про краудфандинг, яке забезпечує є високий рівень захисту інвесторів на рівні ЄС.

Нові європейські вимоги щодо регулювання краудфандингу дозволяють постачальникам краудфандингових послуг (CSP) отримати доступ до всього європейського єдиного ринку за допомогою єдиного дозволу, отриманого в одній державі-члені ЄС.

Положення про краудфандинг містить ряд організаиійних та операиійних вимог, що застосовуються до краудфандингових послуг. Вони стосуються, серед іншого, вимог до капіталу, збереження активів для краудфандингу на основі інвестицій, певних вимог до аудиту, бухгалтерського обліку, аутсорсингу, звітності та ведення документації.

Актуальні вимоги регулювання до постачальників краудфандингових послуг в СС включають обов'язкові умови щодо забезпечення ефективного та обачного управління, в тому числі щодо розробки та впровадження ефективних політик і процедур для забезпечення обачного управління, поділу обов'язків, безперервності бізнесу і запобігання конфліктам інтересів. Постачальники краудфандингових послуг повинні проводити певний рівень належної обачності щодо власників проектів, які пропонують фінансування проектів через краудфандингову платформу CSP в $\mathrm{CC}$, i дотримуватися певних вимог щодо індивідуального управління портфелем кредитів і розгляду скарг.

Положення про краудфандинг також містить певні гарантії захисту інвесторів. У ньому проводиться відмінність між досвідченими і недосвідченими інвесторами і вводяться різні рівні їх захисту, що застосовуються до кожної з цих категорій.

Актуальний режим регулювання краудфандингу в СС вводить вимоги щодо періодів надання певної інформації клієнтам, в тому числі $є$ вимога про надання інвесторам ключової інформації про інвестиції [14].

Ще одним прикладом регулювання надання краудфандингових послуг є Сполучені Штати Америки, де краудфандинг регулюється JOBS Act (Jumpstart Our Business Startups Act), прийнятим у 2012 році для підтримки і спрощення залучення стартового капіталу в стартапах і малому бізнесі [15]. Згідно нього, краудфандингова платформа має бути зареєстрована в комісії з цінних паперів і бірж (The United States Securities and Exchange Commission) і бути учасником FINRA (Financial Industry Regulatory Authority). Цей закон також, як і в $\mathrm{CC}$, встановлює чіткі вимоги, щоб забезпечити інвестора інформацією i, в разі шахрайства або проблем, забезпечити йому захист.

Висновки та перспективи подальших досліджень. Проведене дослідження дозволило виявити перспективний для фінансування малих інноваційних підприємницьких структур (стартапів) інноваційний інструмент - краудфандинг (та його різновид краудінвестинг). Враховуючи, що в Україні, з одного боку, відсутність спеціального регулювання спрощує збір фінансових ресурсів на реалізацію інноваційних проєктів, а з іншого, відсутні будь-які гарантії для вкладених інвестицій, що значно збільшує ризики вкладення коштів в інноваційні проєкти, проаналізовано регуляторну базу ЄС щодо краудфандингу та доведено необхідність її адаптації до нормативно-правової бази України.

\section{ЛІТЕРАТУРА}

1. Global Innovation Index 2020: Who Will Finance Innovation? URL: https://www.wipo.int/edocs/pubdocs/en/wipo_pub_gii_2020.pdf
2. Global
Competitiveness
Report
2019.

URL:

http://www.weforum.org/docs/WEF_TheGlobalCompetitivenessReport2019.pdf

3. Cornelli, G., J. Frost, L. Gambacorta, R. Rau, R. Wardrop, and T. Ziegler. (2020). Fintech and Big Tech Credit: A New Database. BIS Working, Paper 887, Bank for International Settlements, Basel. 
4. Джон Фрост, Леонардо Гамбакорта, Хюн Сон Шин. (2021) От финансовых инноваций к финансовой интеграции. Финансы и развитие. Ежеквартальный журнал Международного валютного фонда. С. 16.

5. OECD (2015). New Approaches to SME and Entrepreneurship Financing: Broadening the Range of Instruments. Synthesis report.

6. Офіційний сайт платформи IndieGoGo. URL: https://www.indiegogo.com/en

7. Офіційний сайт платформи KickStarter: URL: https://www.kickstarter.com

8. Офіційний сайт платформи RocketHub: URL: http://rockethub.com/ dollars).

9. Statista (2018). Total Crowdfunding Volume Worldwide From 2012 To 2015 (in billion U.S.

10. Real Estate Crowdfunding: 3 Trends to Watch in 2017. Forbes, 2017.

11. Краудфандинг. URL: https://internationalwealth.info/startups-abroad/overview-of-the-bestcrowdfunding-sites-to-launch-a-startup/

12. The 4th UK Alternative Finance Industry Report: Entrenching innovation. Cambridge Centre for Alternative Finance, 2017.

13. Краудфандинг: как привлечь инвестиции и реализовать мечту. URL: https://psm7.com/analytics/kraudfanding-kak-privlech-investicii-i-realizovat-mechtu.html

14. Новый европейский режим краудфандинга. URL: https://iqdecision.com/novyj-evropejskijrezhim-kraudfandinga/

15. Gilinsky D., Levites P., Gabbay Z. (2016). Regulation of Crowdfunding in the UK, US and Israel: A Comparative Review. Butterworths Journal of International Banking and Financial Law.

\section{REFERENCES}

1. Global Innovation Index 2020: Who Will Finance Innovation? Retrieved from: https://www.wipo.int/edocs/pubdocs/en/wipo_pub_gii_2020.pdf [in English].

2. Global Competitiveness $2019 . \quad$ Report 2019 from: http://www.weforum.org/docs/WEF_TheGlobalCompetitivenessReport2019.pdf [in English].

3. Cornelli, G., J. Frost, L. Gambacorta, R. Rau, R. Wardrop \& T. Ziegler. (2020). Fintech and Big Tech Credit: A New Database. BIS Working, Paper 887, Bank for International Settlements, Basel [in English].

4. Dzhon Frost, Leonardo Hambakorta, Khiun Son Shyn. (2021) Ot fynansovыkh ynnovatsyi k fynansovoi yntehratsyy [From financial innovation to financial integration]. Fynansbl y razvytye. Ezhekvartalnыi zhurnal Mezhdunarodnoho valiutnoho fonda. S. 16 [in Russian].

5. OECD (2015). New Approaches to SME and Entrepreneurship Financing: Broadening the Range of Instruments. Synthesis report [in English]. English].

6. Official site of the platform IndieGoGo. Retrieved from: https://www.indiegogo.com/en [in

7. Official site of the platform KickStarter. Retrieved from: https://www.kickstarter.com [in English].

8. Official site of the platform RocketHub. Retrieved from: http://rockethub.com/ [in English].

9. Statista (2018). Total Crowdfunding Volume Worldwide From 2012 To 2015 (in billion U.S. dollars) [in English].

10. Real Estate Crowdfunding: 3 Trends to Watch in 2017. Forbes, 2017 [in English].

11. Kraudfandinh [Crowdfunding]. Retrieved from: https://internationalwealth.info/startupsabroad/overview-of-the-best-crowdfunding-sites-to-launch-a-startup/ [in Russian].

12. The 4th UK Alternative Finance Industry Report: Entrenching innovation. Cambridge Centre for Alternative Finance, 2017 [in English].

13. Kraudfandinh: yak zaluchyty investytsii i realizuvaty mriiu [Crowdfunding: how to attract investment and make your dream come true]. Retrieved from: https://psm7.com/analytics/kraudfandingkak-privlech-investicii-i-realizovat-mechtu.html [in Russian].

14. Novyi yevropeiskyi rezhym kraudfandinha [ New European crowdfunding regime]. Retrieved from: https://iqdecision.com/novyj-evropejskij-rezhim-kraudfandinga/ [in Russian].

15. Gilinsky, D., Levites, P., Gabbay, Z. (2016). Regulation of Crowdfunding in the UK, US and Israel: A Comparative Review. Butterworths Journal of International Banking and Financial Law [in English]. 